\title{
Józef Dolina
}

\section{Powstanie i początkowy rozwój zgromadzenia Zmartwychwstania Pańskiego}

Prawo Kanoniczne : kwartalnik prawno-historyczny 21/1-2, 123-141

1978

Artykuł został zdigitalizowany i opracowany do udostępnienia w internecie przez Muzeum Historii Polski w ramach prac podejmowanych na rzecz zapewnienia otwartego, powszechnego i trwałego dostępu do polskiego dorobku naukowego i kulturalnego. Artykuł jest umieszczony w kolekcji cyfrowej bazhum.muzhp.pl, gromadzącej zawartość polskich czasopism humanistycznych i społecznych.

Tekst jest udostępniony do wykorzystania w ramach dozwolonego użytku. 
KS. JOZEF DOLINA CR

\section{POWSTANIE I POCZAZTKOWY ROZWOJ ZGROMADZENIA ZMARTWYCHWSTANIA PANSKIEGO}

Tres ć: Wstęp: 1. Uwarunkowania spoleczne powstania zgromadzenia; 2. Fundatorzy zgromadzenia; 3. Założenie i początkowy rozwój zromadzenia.

\section{Wstęp}

Powstanie zgromadzeń zakonnych wiąże się z podwójną potrzebą: wewnętrzną i zewnętrzną ${ }^{1}$.

Potrzeba wewnętrzna wyraża się w dążeniu do miłości doskonałej droga realizowania rad ewangelicznych. Impulsem takiego postępowania jest nauka i przykład Jezusa Chrystusa. Autentyczne życie zakonne stanowi, według orzeczeń Soboru Watykańskiego II, wybitny znak Królestwa niebieskiego 2 .

Potrzebę zewnętrzną dyktują warunki i wymogi danej epoki. Te warunki i wymogi zewnętrzne okreslają zadania i charakter nowego zgromadzenia zakonnego. Założyciele zakonów kierowali się zwykle potrzebami danego środowiska, w którym żyli. Chcieli przyjść z pomocą Kosciolowi i społeczeństwu. Odczuwali ich troski i kłopoty czasu ${ }^{3}$.

Powstanie zakonu nie realizuje się nagle i niespodziewanie - jak zauważa słusznie o B a r - lecz wokół wybitniejszej jeđnostki skupia się grono osób, które oprócz dążenia do doskonałości przez zachowanie rad ewangelicznych, pragnie spelnic jakies zadanie apostolskie czy charatatywne, co z biegiem czasu staje się celem nowego zgromadzenia zakonnego 4.

Zastanówmy się, jak było $\mathrm{z}$ powstaniem zgromadzenia Zmartwychwstania Pana Naszego Jezusa Chrystusa.

\section{Uwarunkowania spoleczne powstania zgromadzenia}

Fala emigrantów po upadku powstania listopadowego udała się do państw zachodniej Europy. Ogołem znalazło się na emigracji około

1 J. B a r, Polskie zakony, Prawo Kanoniczne, 4 (1964) 423.

2 Perfectae caritatis, n. l. Dekret soborowy z dnia 28. X. 1965 r.

3 J. B a r, dz. cyt., s. 423.

4 J. B a r, dz. cyt., s. 424. 
dziesięciu tysięcy Polaków, w tym czlonkowie Rządu Narodowego, Sejmu, administracji państwowej, adwokaci, dziennikarze, poeci, księża, oficjaliści, rzemieslnicy, chłopi ${ }^{5}$. Dwie trzecie emigracji skupiało się we Francji. Reszta - w innych krajach Europy i na drugiej pólkuli swiata ${ }^{\circ}$. Wszyscy ludzili się, że wkrótce powstaną legiony i w szeregach armii wrócą do kraju. Utworzyły się różne kola, towarzystwa, partie, w których dyskutowano, klócono się, potępiając i wyklinając się wzajemnie ?. Każdy $z$ emigrantów pragnął znaleźć jakieś lekarstwo, by szybciej i skuteczniej uwolnic Ojczyznę spod jarzma zaborcow. W istocie zaś nie chodziło o leczenie, lecz o wskrzeszenie wolnej Polski. Emigracja jednak złożona ze wszystkich stanów społecznych, pozbawiona steru i władzy, do takiego czynu nie była zdolna. Zwaśnieni Polacy nie mogli stworzyć nowego porządku, zdolni byli jedynie do dysput, kłótni, pojedynków ${ }^{8}$. Spośód partii politycznych wybily się dwie: konserwatywna i demokratyczna. Pierwsza - konserwatywna, oparta na zasadach Konstytucji Trzeciego Maja, z Adamem Czartoryskim na czele, widziała zbawienie Polski w monarchii konstytucyjnej, a prawo do tronu przyznawala swemu przywódcy. Natomiast partia demokratyczna szukała ratunku dla Polski w zasadach terroryzmu Wielkiej Rewolucji Francuskiej. Przez swe radykalne zasady chciała poruszyć ludnosć wiejską i w ten sposób wywalczyć wolność dla Ojczyzny?

Rząd francuski, podobnie jak inne rządy krajów Europy zachodniej, był nieprzychylnie, a nawet wrogo ustosunkowany do emigracji polskiej. Taką postawę podsuwała mu obawa przed Rosją oraz niebezpieczeństwo łączenia się emigrantów $z$ organizacjami rewolucyjnymi dzialającymi na terenie Francji. Wysyłano więc emigrantów polskich do Hiszpanii, Algierii, Egiptu. W ten sposób rozpadali się oni na niewielkie grupy i tracili kontakt z resztą rodaków ${ }^{10}$.

Również pod względem religijnym Polacy ponieśli straty. Nie mieli żadnej opieki duchowej. We Francji niemal powszechnie panowal ateizm. Kościoly były puste. Wprawdzie w niedziele bywało na mszy sw. kilka starszych kobiet, ale „kto wie? może żyjących $z$ jałmużn kościelnych" - jak zauważa ks. Semenenko. Panowala zupelna obojętność religijna. Nikt nie prześladowal religii, nikt też o niej nie mówił. Jeśli wspominano o religii, to o jako rzeczy przeszlej, bezpowrotnej, doceniając oczywiście jej zasługi w różnych dziedzinach życia spolecznego ${ }^{11}$.

5 Kieniewicz, Kula, Historia Polski, Warszawa 1959, t. II, cz. III, s. 71 .

- Tamże, s. 72.

7 P. Smolikowski, Historia Zgromadzenia Zmartwychwstania Pańskiego, t. I, Kraków 1925, s. 15.

a. Wielogłowski, Emigracja polska wobec Boga $i$ narodu, Wroclaw 1848 , s. 42.

9 p. Smolik ow ski, dz. cyt., t. I, s. 12.

$10 \mathrm{~W}$. Wielogłow ski, dz. cyt., s. 27-28.

11 P. S molikow ski, dz. cyt., s. 14. 
Wśród Polaków prawdziwe niedowiarstwo było bardzo rzadkim zjawiskiem. Polacy przynieśli do Francji religijność tradycyjną, charakterystyczną dla Słowian, karmiącą się wspomnieniami rodzinnymi, podaniami narodowymi 12.

Stronnictwo liberalne, zwycięsko panujące we Francji, podejmowało Polaków barđzo życzliwie. Opiekowało się nimi, ale wpływem swoim wszczepiało w podatny grunt ${ }^{13}$ swoje uprzedzenia do Kościoła, wciągając i wpisując wybitne jednostki do lóz masońskich.

Jeśli Polska miała istnieć, to zło należało powstrzymać. Wśód Wielkiej Emigracji znalazła się grupa zaledwie kilkunastoosobowa, złączona wspólną myślą - ratowania rodaków przez moralne ich odrodzenie. Nazywano ich „katolikami”. Duchowym wodzem był początkowo autor "Ksiąg narodu i pielgrzystwa polskiego" - Adam Mickiewi c z. Należeli do tej grupy: obaj Z a lescy, Domeyko, Gór ecki, Witwicki, Jański, Wieloglowski, Januszkiewicz i niektórzy młodzi uczestnicy powstania 14. W tym duchu przemawial i pisal wówczas Adam Mickiewicz. Tak myśleli ci, którzy skupili się przy nim. Wkrótce nazwali się Braćmi Zjednoczonymi. O celu tego Bractwa swiadczy akt założenia $z$ dnia 19 grudnia 1834 r., w którym umieścili następujące słowa: „Po umyślnym ku temu odprawieniu świętej spowiedzi łączymy się w związek pod wezwaniem B raci Zjednoczonych. Modlić się codziennie za siebie, Ojczyzne, i bliźnich, za przyjaciół i nieprzyjaciół; przykazania Pańskie słowy i uczynki wypełniać; przykładem swym rodaków do tego zachęcać i na drodze tej wspólną siłą utrzymywać się, jak najmocniej przedsiębierzemy i postanawiamy" ${ }^{15}$. Członkowie stowarzyszenia zbierali się co piątek na mszę sw., a po niej u Wieszcza czytali Pismo sw. i dyskutowali o sposobach ratowania rodaków.

Pewnego razu Mickiewicz przygnębiony wieściami, jakie go z kraju dochodzily i tym co się działo wśród emigracji, zawołal: „Nie ma dla nas innego ratunku, trzeba nowego zakonu. Ale kto go zaloży? Trzeba na to swiętego. Ja? za pyszny. Plater? zanadto arystokrata. Zaleski? zanadto demokrata - Jański założy" 16. I J a ński założył. Pomagali mu w tym dziele Piotr Semenko i Hieronim Kaj$s$ i e wicz.

${ }^{12} \mathrm{H}$. K a j s i e wi c z, Pisma, t. III, Berlin 1872, s. 404.

13 Spoleczeństwo polskie miało żal do Grzegorza XVI, który wprowadzony $w$ błąd przez dyplomację rosyjską i wiedeńska, wydal 9 czerwca 1832 r. do biskupów polskich breve Cum primum, potępiające powstanie listopadowe.

14 B. M ice wski, W kręgu Zmartwychwstańców, Przewodnik Katolicki (1965) 148.

15 Rękopis znajduje się w Bibliotece Jagielońskiej (spuscizna po Zaleskich), podpisany przez Góreckiego, Mickiewicza, Zaleskich, witwickiego, Platera, I. Domeyke, B. Jańskiego. io P. Smolikowski, dz. cyt., t. I, s. 22. 
Tym, którzy kładli podwaliny pod nowe polskie zgromadzenie wypada poświęcić kilka słów.

\section{Fundatorzy zgromadzenia}

Bogdan Jański. Dobrze scharakteryzowal go ks. B. Micewski CR: ${ }^{17}$ „Dziwna to była postać, ten Bogdan Jański, mogloby się zdawać tragiczna postać pełna sprzeczności, jedno pasmo nieudanych prób, poszukiwań i daremnego szamotania się. I to od samego początku do końca." Ja ń s ki urodzil się 26 marca $1807 \mathrm{r}$. w dworku dziadka w Lisowie koło Grójca ${ }^{18}$. Szkołę średnią ukończył w Pułtusku, pod kierunkiem OO. Benedyktynów; 29 lipca 1822 r. zdał egzamin dojrzałości. Jesienią $1822 \mathrm{r}$. objął obowiązki zastępcy profesora w swejej szkole, tzw. kolaboratorstwo, ucząc matematyki, języka polskiego i kaligrafii. Praca pedagogiczna przynosiła mu wiele zadowolenia, mial nawet zamiar zostać stałym profesorem języków. Stało się jednak inaczej. Jesienią 1823 r. rozpoczął studia prawnicze na Uniwersytecie Warszawskim, a po roku zapisał się również na wydział administracji ${ }^{19}$. Studiując encyklopedystów francuskich ochłonął $z$ gorliwości religijnej, zaangażowany najpierw $w$ filozofię ${ }^{20}$, a następnie w ekonomię polityczną ${ }^{21}$. Pod wpływem dziel Holbacha utracil zupelnie wiare. Stał się materialista $i$ ateistą ${ }^{22}$. Studia ukończył w 1827 r. ${ }^{23}$. Po ukończeniu studiów pracował $w$ redakcji Kuriera Warszawskiego jako tłumacz, autor $\mathrm{i}$ korektor 24 .

W 1827 r. Jański, jako jeden z najzdolniejszych absolwentów Uniwersytetu 25 , po zdaniu egzaminu konkursowego, został wytypowany jako kandydat na wyjazd do Francji, Anglii i Niemiec dla podjęcia

17 B. M i ce w s ki, dz. cyt., s. 148.

18 Według najnowszych badań ks. Micews $\mathrm{k}$ i ego któremu udało się dotrzeć do aktu ślubu B. Jań $\mathrm{s}$ i i go $\mathrm{i}$ wpisu do księgi studentów Uniwersytetu Warszawskiego.

${ }_{19}$ B. M ice w ski, Jański Bogdan Teodor Ignacy. W: Hagiografia Polska, t. I, Poznań 1972, s. 605.

20 Określenia Jańskiego w Dzienniku: „egzaltacja filozoficzna”, „kancista", "spiritualista".

21 B. M i c e w s ki, dz. cyt., s. 605.

22 Tamże.

23 Magisterium z prawa zdobyl 10 lipca, a $\mathrm{z}$ ekonomii politycznej 24 października $1827 \mathrm{r}$. Por. j/w.

${ }_{24}$ B. M i ce w s ki, dz. cyt., s. 606.

25 Już w 1825 r. napisal rozprawę konkursową $z$ ekonomii politycznej pt.: „Jaki może być wpływ upowszechnienia zasad ekonomii politycznej na podział bogactw i moralnosć narodu", która jako zbyt śmiała nie została nagrodzona, ani wyróżniona, ale zwróciła uwage prof. F. Skarbka. Podjąı się także przekładu obszernej pracy z języka francuskiego H. Storcha „Ekonomii politycznej”. Pracę zasygnalizowała prasa. Wydano ją znacznie później w trzech tomach, bez podania tlumacza. Por. B. M i c e w s ki, dz. cyt., s. 605. 
studiów przygotowawczych na profesora organizowanego Instytutu Politechnicznego $\mathrm{w}$ Warszawie ${ }^{26}$. W przeddzień wyjazdu na studia ${ }^{27}$ ożenil się $\mathrm{z}$ Aleksandrową $\mathrm{Z}$ awa $\mathrm{dzk}$ ą, chąc ją ratować $\mathrm{z}$ tragedii $\dot{z} y-$ ciowej.

Małżeństwo to uważał w późniejszym czasie za katastrofę życiową, gdyż utrudniło mu realizowanie myśli o kapłaństwie. Jański studiując w Paryżu, żywo interesowal się nowymi ruchami ekonomiczno-spolecznymi. Wstąpił w szeregi Saintsimonistów ${ }^{28}$. Był zresztą pierwszym cudzoziemcem i jedynym Polakiem wsród nich. Stało się tak, gdyż odkrył $\mathrm{w}$ tej idei wielkie podobieństwo ze swoimi planami warszawskimi. Uwierzył, że ich wewnętrzne zespolenie i piękny program istotnie zdolny jest uszczęśliwić ludzkosć, potępiając pasożytnictwo społeczne, wyzysk i bagactwo bez pracy, oparte na dziedziczeniu i mnożeniu się kapitału, wynosząc bohaterstwo twórczej pracy a nie zabijanie się $w$ wojnie. W organizacji, w skład której wchodzili znani ekonomiści, filozofowie, studenci i robotnicy $\mathrm{z}$ utworzonych zakładów na zasadzie równości i sprawiedliwości wynagrodzeń, widział zalążek nowego i sprawiedliwego ustroju społecznego. Od sierpnia $1830 \mathrm{r}$. do lutego $1831 \mathrm{r}$. przebywał $w$ Londynie, gdzie pertraktował $z$ wybitniejszymi Anglikami, szczególnie z Robertem $\mathrm{O}$ we nem, aby ich pozyskać dla saintsimonizmu ${ }^{29}$. Nie zaniedbywał swoich studiów. Starał się utrzymać kontakty $z$ czołowymi przedstawicielami angielskiego ruchu umysłowego ${ }^{30}$. Kiedy Jański przygotowywał się już do powrotu do kraju, w Polsce wybuchło powstanie. Otrzymał tajny rozkaz od rządu powstańczego na Zachodzie dla rozwinięcia akcji politycznej na rzecz powstania ${ }^{31}$.

Jański utracił wiarę, ale $\mathrm{w}$ jego duszy było to, co możemy nazwać religią naturalną. Szukał Boga, tęsknił za Nim. Jako saintsimonista pisze: „Chcę żyć w świątyni wielkiego Boga, đo niej wołać całą ludzkość" 32. Saintsimonizm nie dał mu satysfakcji. Po powrocie z Londynu, kiedy $J$ ański wybił się na czoło ruchu socjalistów utopijnych - występuje $z$ ich szeregów. Upadek powstania listopadowego, a przede wszystkim kłótnie i rozłam wśród przywódców saintsimoni-

26 Tamże, s. 606 .

27 Według aktu ślubu i Dziennika podróży B. Jańskiego.

$28 \mathrm{~S}$ a int-S im on Klaudiusz napisal w 1825 r. pracę pt.: Nouveau christianisme, w której twierdził, że dotychczasowe chrzescijaństwo już się przeżyło, że trzeba je zreorganizować. Uczniowie jego: A. B a z a r d, B. P. Enfantin, L. H. Carnot i M. Chevalier glosili haska tzw. komunizmu utopijnego. Zarząd swój wzorowano na hierarchii Kościola Katolickiego. Panteistyczna i-kosmopolityczna ideologia miała charakter nowoczesnej religii i ogłosiła siebie nowym chrześcijaństwem.

${ }_{29} \mathrm{~W} . \mathrm{K}$ wiatkowski, Historia Zgromadzenia Zmartwychwstania Pańskiego, Albano 1942, s. $7-8$.

${ }^{30} \mathrm{~W}$ notatkach zapisanych w Dzienniku $\mathrm{z}$ okresu jego pobytu w Londynie spotykamy takie nazwiska, jak J. Mill, MacCulloch, A. H a y w a rd, J. H u me.

31 B. Mic e w s ki, dz. cyt., s. 607.

32 P. Smolikow ski, dz. cyt., t. I, s. 5. 
zmu, a wreszcie upadek samego ruchu, podziałały na niego otrzeźwiająco. Odszedı zrażony i zachwiany $w$ wierze $w$ moc ideałów smiałych reformatorów ${ }^{33}$.

Do Francji przybywają rzesze emigrantów z Polski. Jański jak zawsze czynny, oddal się z całym zapałem pracy społecznej, charytatywnej i politycznej ${ }^{34}$. Pracowal nad pojednaniem rodaków-emigrantów. Było to jeszcze przed jego nawróceniem.

$\mathrm{Na}$ początku $1832 \mathrm{r}$. zaczął skłaniać się ku katolicyzmowi. Jański zbliżył się do Adama Mickiewicza, z którym przez pewien czas mieszkal. Kontakt $\mathrm{z}$ M i ckiewi $\mathrm{czem}$, który przeźywał okres gorliwości religijnej, dyskusje $\mathrm{z} L \mathrm{~L}$ a ordairem, Montalembertem, lektura dzieł filozoficznych i teologicznych - pozwolily mu pod koniec 1832 r. wrócić do Boga i Kościoła. Uwieńczeniem jego nawrócenia była sześciotygodniowa spowiedź $w$ pięciu etapach ${ }^{35}$. 11 stycznia $1835 \mathrm{r}$. zapisal w swoich notatkach: „Dzień $w$ moim życiu na zawsze uroczysty. Dzień nowego przymierza mego z Bogiem!... Komunia swięta ${ }^{30 . " ~ O d-~}$ tąd stał się gorliwym apostołem. Wiele trudow i zabiegow podejmował, aby rodakom przywrócić utraconą wiarę ${ }^{37}$. Znał wszystkich, którzy byli w potrzebie materialnej lub moralnej. Dowiadywal się także o tych, którzy mogliby przyjść z pomocą potrzebującym. Aby przyspieszyć ich nawrócenie, sam zapewnial im utrzymanie. Stanowil pewnego rodzaju biuro informacyjne ${ }^{38}$. Był gorącym patriotą $\mathrm{i}$ - jak pisze Witwicki „Polakom przez polską szybę w niebo patrzeć kazal”.

Musimy pamiętać, że Jański był ekonomistą. Aby rozwinąć swą działalność ułożył plan Bractwa Służby Narodowej. Głównym celem Bractwa miało być wprowadzanie zasad chrześcijańskich w życie publiczne i prywatne. Miało ono być niewygasłym ogniskiem wiary, nadziei, milości chrześcijańskiej i ducha narodowego. Srodkiem zabiezpieczenia jedności Członków miała być modlitwa za Ojczyznę i w intencji Bractwa. Działalność Bractwa Jański chciał wprowadzić we wszystkie dziedziny życia społecznego. Dla tych, którzy byli złamani życiem, pragnął urządzić domy rekolekcyjne. Dla biednych - bractwa milosierdzia. Natomiast przytułki w większych skupiskach wychodźctwa polskiego. Mając na uwadze podniesienie poziomu intelektualnego Polaków, pragnął założyć: biblioteki, czytelnie, wydawnictwo dzieł naukowych i czasopism; stworzyć agencję prasową w języku francuskim dotycząca spraw polskich oraz utworzyć polski uniwersytet katolicki. Miał nawet gotowy plan. Myślał o zalożeniu domu dla studentów polskich przy Katolickim Uniwersytecie $w$ Belgii. W tej sprawie kansultowal się z IM o n-

38 Tamże, s. 8.

34 Tamże, s. 9.

35 24 listopada, 6 grudnia, 29 grudnia 1834 r., 5 stycznia i 10 stycznia 1835 roku.

36 B. J a ń s k i, Dziennik.

$37 \mathrm{~S}$. Wit w i ki, Wieczory Pielgrzyma, t. II, Paryż 1845, s. 124.

38 W. K wiatk o w s ki, dz. cyt., s. 11 . 
ta le mbert em. Aby podniesć poziom intelektualny i moralny duchowieństwa polskiego plonowal utworzenie Kolegium Polskjego w Rzymie. Mając na uwadze potrzeby polityczne i ekonomiczne, zamierzał założyć biuro wywiadowcze w Paryzu, wydawnictwo pisma politycznego, szkołę wo.jskową i przemysłową w Anglii ${ }^{39}$.

Od początku 1836 r. w notatkach Jańskiego bardzo często pojawiają się wzmianki o zamiarach i wysiłkach zmierzających do zorganizowania życia wspólnego. Zdawał on sobie bowiem sprawę, że powodzenie i realizowanie powyższego planu musi się oprzeć na trwałym związku osób owładniętych tym samym duchem i celem: dążenia do doskonalości własnej i rodaków.

Dnia 21 lutego 1836 r. w środę popielcową wraz z uczniami: Piotrem Semenką i Hieronimem $\mathrm{Kajsiewiczem,} \mathrm{zamieszkał} \mathrm{w} \mathrm{wynaję-}$ tym domku przy ulicy Notre Dame des Champs 11.

Pi otr Semenenko. Urodzil się 29 czerwca 1814 we wsi Dzięciolów kolo Tykocina. Ojciec jego byl oficerem carskim, a później urzędnikiem w Pińsku. Piotr był wychowywany przez babcię kalwinke, uczęszczał jednak do szkoły prowadzonej przez Księży Misjonarzy, gdzie przy jął potajemnie pierwszą Komunię św. Ukończyl gimnazjum w Krożach. Mając 15 lat rozpoczął studia na uniwersytecie $w$ Wilnie. Brał udzial w powstaniu listopadowym. Wraz z korpusem Gielguda i Chłapowskiego wszedł do Prus. Tam zapoznał się $z$ filozofią niemiecką. W 1832 r. przybył do Besançon, głównego skupiska Polaków. Znalazł się w srodowisku młodzieży akademickiej, podoficerów i żołnierzy. Kiedy w Chateauroux rząd francuski utworzył zakład dla emigracji cywilnej, osiemnastoletni Semenenko prowadzil wykłady z zakresu historii powszechnej. Wiersze pisane $w$ owym czasie przez niego tchną zemstą i nienawiścią ku wszelkiej władzy. Wydalony $z$ Chateauroux przez miejscowego prefekta, musiał się ukrywać w Paryżu. Tam był wspólpracownikiem lewicowego czasopisma Postęp oraz pisywał we francuskiej Trybunie. Wstąpil do świeżo założonego przez Adama Gu rows k i e go Towarzystwa Demokratycznego Polskiego. W czasie obchodów rocznicy powstania listopadowego wystapił $\mathrm{z}$ gwaltownym atakiem przeciw Czartoryskiemu i szlachcie polskiej. Należał też do loży masońskiej. Scigany przez policję francuską jako niebezpieczny anarchista, przez dwa lata musiał się ukrywać i przenosis $z$ miejsca na miejsce. Zazdrośni o jego wplywy polityczne rodacy, zaczynają mu wytykać jego pochodzenie $z$ ojca Rosjanina, a nawet posądzać o szpiegostwo. Jański tymczasem sam przygotowując się do spowiedzi, starał się Semenenkę również doprowadzić do konfesjonału. 21 stycznia 1835 r. Semenenko przystappił do spowiedzi. Następnie 15 lutego wydał list otwarty do swoich przyjaciół i nieprzyjaciól odwołując błędy i prze-

39 Wyjątki z Planu Bractwa Slużby Narodowej zamieszczone zostały w Historii Zgromadzenia ks. S moli kow k iego i ks. K wiatkowskiego.

- Prawo kanoniczne 
praszając za zgorszenie; wzywał ich, by poszli tą samą drogą, którą teraz obrał. Odtąd zamieszkał Semenenko z Jańskim, modląc się i czytając książki katolickie ${ }^{\mathrm{O}}$.

Hieronim Kajsiewicz. Urodzil się 7 grudnia $1812 \mathrm{r}$. w powiecie mariampolskim. Po ukończeniu gimnazjum $w$ Sejnach $w 1829$ r. udal się na uniwersytet $\mathrm{w}$ Warszawie $\mathrm{i}$ studiowal na wydziale prawa i administracji. Biorąc udział $w$ powstaniu listopadowym $w$ korpusie $\mathrm{Dwernickiego}$ zostal ciężko ranny. Po nieudanym powstaniu wyemigrowal do Francji. Odznaczal się zdolnościami poetyckimi. Wstąpił do loży masońskiej.

W 1835 r. spotkał się z Adamem Mickiewicze m. Będąc już kaplanem opowiadał, że po raz pierwszy zaczął myśleć o religii wtedy dopiero, kiedy nie zastawszy Mickiewicza w jego domu, usłyszal od służącej poety: „Pan Mickiewicz o tej godzinie jest zawsze na mszy swiętej”. "Uderzyło to mnie - mówił ks. Kajsiewicz i pomyślałem sobie: jeśli Mickiewic $z$ chodzi do kościoła, to religia musi być czymś przecie poważnym". Pod wplywem dalszych osobistych kontaktów dokonała się calkowita, wewnętrzna przemiana $\mathrm{Kajsie-}$ wic z a ${ }^{41}$.

\section{Założenie i początkowy rozwój Zgromadzenia}

Wkrótce do tej małej grupy przyłączyli się: Józef Ma liński malarz; Edward Dúnski - byly student warszawski i oficer piechoty; Józef $\mathrm{Hube}$ - byly wykladowca Uniwersytetu Warszawskiego; Hipolit Terlecki - doktor medycyny i chirurgii; Karol Kaczan owski - inżynier i były kapitan artylerii 42 . Niedlugo potem dom ten zaczęto nazywać „domkiem Jańskiego”. J a ński, jako „brat starszy", ustalił pewien regulamin, według którego prowadzili życie na sposób zakonny. Wszystko u nich było wspólne, a szczególnie: godziny wstawania, modlitwy, czytania duchowne, msza św. J a ński głosil konferencje duchowne, Semenenko odczyty $z$ teologii, $\mathrm{Kaj}$ $\mathrm{siewicz} z$ liturgii. Dzień kończyl się wzajemnym przeproszeniem ${ }^{43}$.

Zaczęły pojawiać się również kłopoty. Jedni uważali, że „domek Jaskiego" został założony i byl finansowany przez arystokratów, inni przez jezuitów. W ezasopismach ukazały się oszczercze artykuły. Jeszcze inni uważali, że pod płaszczykiem religijnego stowarzyszenia za-

10 Por.: P. S molik ow ski, dz. cyt., t. I, s. 26-33; K w i t k owski, dz. cyt., s. 13-14; M. P i a tkow ski, Semenenko Piotr Adolf Konstanty. W: Hagiografia Polska, t. II, Poznań 1972, s. 314-315.

4 Por.: P. Smolikowski, dz. cyt., t. I, s. 34-47; J. Mrowczyński, Kajsiewicz Ambroży Józef Hieronim. W: Hagiografia Polska, t. I, Poznań 1971, s. 661-684.

${ }_{42} \mathrm{~K}$ wi a t k a w s ki, dz. cyit., s. 12.

4s $\mathrm{S}$ molik ow s ki, dz. cyt., t. I, s. 63. 
wiązała się nowa partia polityczna. Cezaremu Platerowi, który chodził $w$ ich sprawie do ministerstwa powiedziano wprost, że nie wierzą w pobożnośc dawnych wojskowych $i$ że w tym wszystkim musi być polityka. Policja pod różnymi pozorami dokonywała rewizji ${ }^{44}$. Oprócz tego borykano się z trudnościami finansowymi. Jański przyjmowal do "domku" każdego, kto tylko wyraził chęć pozostania w nim. Często przychodzili ludzie biedni i zadłużeni. Jański starał się regulować ich długi. Ciągle więc był deficyt $w$ kasie ${ }^{45}$.

Kiedy Semene nko i Kajsie wi c z wyrazili chęć poświęcenia się pracy kapłańskiej, Jański starał się o umieszczenie ich $w$ jakimś seminarium duchownym. Niestety, władze seminaryjne bały się ich przyjąc z racji politycznych. Ostatecznie doszedı do porozumienia z ks. A u gè, dyrektorem Collège Stanislas - zakładu wychowawczego dla młodzieży. Tam mieli spełniać funkcje wychowawców (z wynagrodzeniem 400 franków rocznie) i studiować teologię ${ }^{46}$. 29 czerwca Semenenko i Kajsiewicz wstąpili do Collège Stanislas ${ }^{47}$, a 15 sierpnia otrzymali sutanny. Tam téz studiowali następni uczniowie Jańskiego. Po rocznym pobycie $w$ Collège Stanislas $\mathrm{J}$ an $\mathrm{ski}$ wysłal Semenenkę i Kajsiewicza na dalsze studia do Collegium Romanum ${ }^{48}$. Pod koniec 1838 r. do Rzymu przybyli J. H u be i E. D uński. Utworzyli tam tak zwany "domek rzymski". Przełożonym wybrali s e men e nkę. Tryb życia prowadzili według zasad wypróbowanych w „domku" paryskim.

J a ńs ki miał teraz nowe kłopoty. Musial utrzymać „domek” paryski i rzymski, wspomagając je duchowo i materialnie. Stał on na stanowisku nie lączenia się z żadną partią polityczną ${ }^{49}$, wyciągając wnioski z przykrych doswiadczeń. Cezary P l a te r postanowił udaremnić dzieło J a ński e go i uzależnić je od siebie. W tym celu 24 grudnia 1838 r. przybył do Rzymu. Uczniowie J a ńskiego przyjęli go do siebie, traktując jako swego dobroczyńcę. Plater oskarżał Jańskiego przed M ontalembertem, ze jest niebezpiecznym reformatorem społecznym, kryjącym się pod płaszczykiem religii. $\mathrm{Z}$ tym faktem łączą się

44 S m o li k o w ski, dz. cyt., t. I, s. 62.

45 M i cki e wicz tak opisuje Zaleskim stan „domku": „Wiem, żescie mu przysłali pomoc i pytaliście nas o stan potrzebujących. W domu jest zdawna deficyt i bezład finansowy. I nie podobna żeby było inaczej. Dom przyjmował osoby różne $z$ żoldem i bez żoldu, prawie zawsze zadlużone. Wszystkie długi spadają na korporację i tych nawet co ją porzucili, trzeba dźwigać ciężary." Zab.: $\mathbf{S}$ m ol i k o w s k i, dz. cyt., s. 71.

46 Collège Stanislas, byl to zakład dla uczącej się mlodzieży, założony w 1804 r., przez ks. L i a u tard, ks. A ugè i ks. Froment. Nazwe Stanislas nadał zakładowi Ludwik XVIII w $1822 \mathrm{r}$. dla uczczenia pamięci króla Stanisława Leszczyńskiego. Por.: Histoire du Collège Stanislas par M. L'abbe De Le gard, s. 106.

$17 \mathrm{~J}$ a ń $\mathrm{s} \mathrm{k} i$, Dziennik.

$48 \mathrm{~K}$ i a t k ow $s \mathrm{ki}$, dz. cyt., s. 22.

$19 \mathrm{~W}$. Kos iński, Duch na czasie, t. I, Rzym 1961, s. 120, 211, 212; t. II, Rzym 1966, s. 88-90, 104-105. 
także inne, jak likwidacja listów pisanych do $\mathrm{J}$ a ń $\mathrm{s}$ ki e go ${ }^{50}$ i akcja udaremniająca działalność jago w Paryżu. Do wladz Collège Stanislas wpłynęły falszywe oskarżenia pod adresem Jańskiego złożone przez Jelowickiego i Kamockiego ${ }^{51}$. Wreszcie Plater napisal otwarcie, że zobowiązuje się pokryć wszystkie długi „domku” pod warunkiem, że Jański opuści Paryż i przybędzie do Rzymu 52 .

Zakończyło się tak, jak sobie życzył Plater. Jański przybyl do Rzy$\mathrm{mu}$ już $\mathrm{w}$ ostatnim stadium gruźlicy. Umarł 2 lipca 1840 r. w opinii \$więtosci, przeżywszy 33 lata ${ }^{53}$.

Zgon J ánski e go odbil się silnym echem nie tylko wśród jego uczniow i emigracji, lecz także w Ojczyźnie. „Historia Jań s kiego pisał Jan Koźmian w Przeglqdzie Poznańskim ${ }^{54}$ - jest podobna do (historii) wszystkich bohaterów Koscioła. Żyl krótko, wiele cierpiał, wiele kochał... $\mathrm{Z}$ miłości dla Boga i dla kraju powziąı mysl wielką, rozbudzenia życia chrześcijańskiego $w$ duchowieństwie polskim $i$ podźwignienia Ojczyzny z umyslowego i moralnego upadku. Położyl kamień węgielny nowego zakonu, na ten cel przeznaczonego, umarł $z$ trudu wprzód, nim się myśl jego urzeczywistnić mogla..."

Przed młodymi adeptami kapłaństwa stanął obowiązek realizowania rozleglych planów i zamiarów Jańskiego. W Rzymie mieli podwójny obowiązek: informowania Stolicy Apostolskiej o sytuacji Kościoła na ziemiach polskich i zbliżenie Polaków do papieża. W Paryżu pozostawil im potrójne zadanie: utrzymanie „domku” Jańskiego i prowadzenie zakładów naukowych dla młodzieży polskiej, aby ją uchronić od wielkomiejskiego zepsucia; wydawanie dzieł religijnych; organizowanie nabożeństw polskich dla emigrantów ${ }^{\mathbf{5 5}}$.

Dla uregulowania powyższych zadań wspołbracia wysłali Edwarda Dúnski ego do Paryża. Ten zbieral przyjaciół Jańskiego i odbywal z nimi narady. Rzecz dziwna, rozporządzenia mlodych kleryków znalazły posłuch. Ustalono więc, że „domek" w Paryżu musi egzystować. Postanowiono $\mathrm{w}$ jednym $\mathrm{z}$ kościolów paryskich zaingurować nabożeństwo dla rodaków. Ponieważ nie mieli wsród siebie kapłana, poruczon tę misję ks. Koryckiemu. Pierwsze nabożeństwo zostalo odprawine 27 wrzesnia 1840 r. w kościele Nôtre Dame de Victoire o godz.

50, ,Z Rzymu przed kilku dniami miałem list, z którego widzę, żem poprzedniego, obszernego znowu aź dotąd nie otrzymal." Zob. list J a ńsk i go do Wieloglowskiego z 20 sierpnia 1839 r. Biblioteka Polskiej Akademii Nauk (BPAN) sygnatura 1835.

${ }_{51}$, ,Dziś $\mathrm{z}$ rana miałem pójsć do Collège, ale dowiedziawszy się $\mathrm{i}$ wymiarkowawszy moje względem dyrektorów położenie dzisiejsze, przez różne gadaniny i wpływy Jelowickiego i Kamickiego, wolałem nie pojjśc." Por.: List do Wielogtowskiego z 15 lipca 1839 r. (BPAN).

${ }_{52}$ Jak wynika z listu $\mathrm{J}$ a ńs $\mathrm{k}$ i e go do Wieloglowskiego z 3 lipca 1839 r. (BPAN).

5s S molik ow ski, dz. cyt., t. II, s. 275.

$54 \mathrm{Sm}$ olik ow ski, dz. cyt., t. II, s. 290 .

$55 \mathrm{Now}$ od w orski, Encyklopedia Kościelna, t. 33, s. 278. 
$12.00^{56}$. Rozpoczęto również wtedy wydawnictwo dzieł religijnych ${ }^{\text {57. }}$ Dnia 2 listopada tegoż roku otworzono pensję dla uczącej się młodzieży, której kierownictwo objął Jan $\mathrm{K}$ oź m i a n ${ }^{58}$.

Działalność przyszłych Zmartwychwstańców była ograniczona. Wszyscy oczektwali na pierwszych kaplanów. Mimo sprzeciwu ambasady rosyjskiej, w dniu 5 grudnia 1841 r. Piotr Seme nenko i Hieronim $\mathrm{K}$ a j si e wi $\mathrm{z}$ otrzymali swięcenia kapłańskie ${ }^{59}$.

Wkrótce, bo już 9 stycznia 1842 r., otrzymali je J. Hube i E. Duń$\mathrm{ski}$. 00 .

Na młodych kapłanów czekała ciężka praca. Z Paryża wciąż alarmowano, aby przybyli rozprawić się $z$ towiańszczyzną.

Przewidując prawdopodobieństwo i potrzebę rozlączenia się, postanowili związać się ślubami. Uważali, że związek ich poprzez ten akt będzie trwaly ${ }^{\circ 1}$.

Przez cały Wielki Post 1842 r. siedmioosobowa grupa: ks. S e m ene nko, ks. Kajsiewicz, ks. Hube, ks. Dunski, Kaczanowski, Terlecki, Godlewski - pracowala nad ułożeniem Reguły. Po przedyskutowaniu poszczególnych artykułów, ostatniej redakcji dokonal ks. P. Semene nko62. W Wielką Sobotę, 26 marca dokonano wyboru przełożonego, którym został ks. P. Semenenko. Regułę podpisano 27 marca $1842 \mathrm{r}$.

Zastanawiano się nad nadaniem nazwy stowarzyszeniu. Ktos z obecnych podsunął myśl: „Wypada nam przyjąć miano, które sam Bóg daje wskutek aktu związania się naszego Zgromadzenia $i$ to bez uprzedniego rozmysłu, w rocznicę Zmartwychwstania Pańskiego "3." Odtąd nazywano się Braćmi Zmartwychwstania. O godzinie piątej rano udali się wszyscy do katakumb sw. Sebastiana, gdzie po mszy sw. ks. Semenenko jako przełożony, złożył śluby wobec Boga $\mathrm{i}$ wspólbraci. Pozostali złożyli je na ręce ks. Semenenki. Sluby te miały charakter prywatny. Oprócz zainteresowanych byli obecni: nowicjusz Zaleski i rodzina Wieloglowskich 4 .

Nazwy „Zmartwychwstańców" postanowiono nie używać ze względów politycznych. „Dla nas - jak pisze ks. Ka jsiewicz - wyrażało ono (zmartwychwstanie) odrodzenie się wewnętrzne $w$ nas, $w$ na-

${ }^{56}$ P. S m o lik ow s ki, dz. cyt., t. II, s. 299.

57 Tamże, t. II, s. 300 .

58 Tamże, t. II, s. 308.

50 Tamzie, t. II, s. 345 .

6o P. S m olik ow s ki, dz. cyt., t. II, s. 349.

61 Tamże, t. III, s. 7.

62 Tamże.

${ }^{63} \mathrm{~K}$ a j s i e wicz, Pisma, t. III, Kraków 1872, s. 426.

os P. S m o $1 \mathrm{ik} \mathrm{ow} \mathrm{s} \mathrm{ki,} \mathrm{dz.} \mathrm{cyt.,} \mathrm{t.} \mathrm{III,} \mathrm{s.} 10$. 
rodzie naszym i innych, do których nas Bóg na prace posłal ${ }^{65}$." Nazywano ich różnie: „Księża Polscy”, „Klasztorek Polski”.

Nowe stowarzyszenie, zgodnie $\mathrm{z}$ zalożeniem Jańskiego, miało pracować przede wszystkim wśód emigracji i dla niej, a póńniej w Polsce, by podźwignąć poniżony wówczas i uciemiężony Kośció ${ }^{66}$.

Po złożeniu slubów na młodych zmartwychwstańcow czekała praca apostolska. W Rzymie, gdzie oddano im francuski kościól sw. Klaudiusza zorganizowali nabożeństwa dla emigrantów i pielgrzymów polskich ${ }^{67}$. W Paryżu prowadzili walke $z$ towiańszczyzną. ${ }^{68} \mathrm{Ks}$. K a js i ewi cz wkrótce dał się poznać jako wybitny kaznodzieja, głosząc misje dla Polaków w Tuluzie, Tours, Angers, Beauwais, a w następnych latach $w$ Brukseli i w Londynie.

Zmartwychwstańcy pragnęli rozwinąc swoją działalnosć na ziemiach polskich. W lipcu 1842 r. ks. Semenenko, zaproszony przez arcybiskupa Marcina Du nina, wyruszal z Rzymu do Wielkopolski. Pragnął on przez swoją wizytę zapoznać się z sytuacją polityczną, umożliwiającą osiedlenie się zmartwychwstańców w Poznaniu i ewentualne objęcie, na życzenie arcybiskupa, kierownictwa seminarium duchowego ${ }^{70}$. Został bardzo serdecznie przyjęty przez arcybiskupa poznańskiego. Policja odmowiła ks. Semenence pozwolenia na pobyt w Poznaniu. Prezydent miasta dal natomiast pozwolenie na pobyt tymczasowy 71. Arcybiskup wówczas zwrócil się do króla i ministerstwa w Berlinie $z$ prosbą o wyrażenie zgody na mieszkanie ks. Semenenki w jego diecezji oraz na danie „posady” jemu i jego towarzyszom, księżom - wygnańcom ${ }^{72}$. Czekając na odpowiedź ministra, ks. S e me n e nk o spowiadal, uczestniczył w konferencjach naukowych i religijnych.

o5 Tamże, t. III, s. 7.

${ }_{66}$ J. B a r, dz. cyt., s. 364 .

67 „Podobało się Bogu dać nam dowód zewnętrzny, że On nas natchnąl przyjętą przez nas nazwą Zmartwychwstańców. W jesieni bowiem tegoż roku (1842), bez najmniejszego zachodu $z$ naszej strony, za staraniem księżnej Borghese matki, z domu La Rochefoucault, otrzymaliśmy $w$ administrację jeden $z$ kościolow francuskich w Rzymie, dawniejszy prowincjonalny Burgundczyków, a poswięcony sw. Andrzejowi Apostołowi Słowian i św. Klaudiuszowi. Kościół ten był nam całkiem nieznany, ... z jakimże miłem zdziwieniem, znaleźliśmy jeden $z$ trzech oltarzów poświęcony zmartwychwstaniu Pańskiemu, i ozdobiony pięknym obrazem tej tajemnicy. Tem to dziwniejsze, że dotychczas nie slyszeliśmy o drugim oltarzu poświęconym zmartwychwstaniu w całym Rzymie." K a jsie wi c z, Pisma, t. III, s. 426.

o8 Smolik ow ski, dz. cyt., t. IV, rozdz. I i II. O dzialalności Zmartwychwstańców w Paryżu napisał ks. M. Traczyński pracę magisterską pt.: Działalność Misji Polskiej $w$ Paryżu $w$ latach 1842-1904 .

${ }^{69} \mathrm{~K}$ a j s i e w i c z, dz. cyt., t. III, s. 434 .

$70 \mathrm{~W}$. Kosińs i, Duch na czasie, t. II, s. 35; Smolikowski, dz. cyt., t. III, s. 146.

${ }^{71}$ S m olik o w s k i, dz. cyt., t. III, s. 139.

$72 \mathrm{~K}$ os ińs k i, dz. cyt., t. II, s. 61 . 
Spotkał się wówczas między innymi z Marcinkowskim, M oraczewskim, Cieszkowskim, Libeltem. Odwiedzil generała Chlapowskiegow Turwi ${ }^{73}$. Wkrótce pojawiły się w dziennikach protestanckich artykuły zwracające uwagę, że w Poznaniu miejscowi jezuici (tak nazywano gorliwszych księży, gdyż jezuitów faktycznie wówczas w Wielkim Księstwie Poznańskim, na skutek kasaty, nie było), sprowadzili przebieglejszego jezuitę z Rzymu i że konfesjonał jego jest oblężony. Akcja przeprowadzona przez owe dzienniki udaremnila nadzieje ks. Semene nki i przyczyniła się do tego, że po dwumiesięcznym pobycie otrzymał nakaz opuszczenia Księstwa $i$ to na stałe ${ }^{74}$. Wracając do Rzymu w Brukseli mial dlugą rozmowę $z$ Towiańskim ${ }^{75}$.

Przyszła jeszcze jedna próba na młodych zmartwychwstańców. Stowarzyszenie, aby mogło się rozwijać potrzebowało nowicjatu. Wszyscy go odbyli w ,domku" Jańskiego. Wydawało im się, że nie byl to formalny nowicjat. Szukając wzoru dla własnego nowicjatu, ks. Semenenko postanowil go odbyć u księży misjonarzy. 16 grudnia 1843 r. pisał d ks. Kajsiewicza: „Utworzenie nowicjatu jest rzeczą konieczną, ale tę rzecz trzeba dobrze i wytrawnie zaprowadzić. Jednym słowem, improwizować nie można. I dlatego Bóg dobry zdaje się dał tę myśl, abym wszedł sam na czas jaki do któregoś nowicjatu, tam się przypatrzył i wyćwiczył w całym toku życia zakannego, a szczególniej przemedytował wszystkie nasze obowiązki, wpoił je siebie, zasięgnął rady ludzi doświadczonych - i tak przygotowawszy się, o ile można będzie najlepiej za laską Bożą, wtedy dopiero założyć nowicjat dla innych, dla nas wszystkich." 76 W dalszej częsci listu ks. Semenenko prosi o przedłożenie swojej prośby ks. Et ienne, przełożonemu generalnemu księży misjonarzy. Ks. Etienne dał, odmowną odpowiedź, powołując się na konstytucje, według których nie wolno przyjmować obcych do nowicjatu 7 . Zaprponował ks. Ka jsie wicz owi połączenie się z misjonarzami i przyjęcie reguły św. Wincentego. Zaznaczył, że mogą pracować dla Ojczyzny wśród emigracji i w Polsce. Chcial im oddać pod zarząd wszystkie domy zgromadzenia w Polsce, zarząd seminariów, szkół, domów sióstr, z prawem dokonania zmian $i$ reform według potrzeb ${ }^{78}$. Dodał, że trzeba na to swiętego, aby się udało założenie nowego zgromadzenia.

Ks. Semenenko dnia 9 lutego pisze do ks. Kajsiewicza: „Gdybysmy byli woluntariuszami, byłaby to rzecz arcykorzystna. Teraz cała kwestia do tego się sprowadza, czy nasza gromadka było to dzieło Boże, które Bóg zawiązał, dał mu łaski szczególne, szczególnego

73 Tamże, s. 64.

74 Tamże, s. 62.

${ }^{75} \mathrm{~K}$ a j s i e wi c z, Pisma, t. III, s. 435.

$76 \mathrm{Smolik}$ ow ski, dz. cyt., t. III, s. 156.

77 Tamże, s. 157.

${ }^{78}$ List ks. Ka mockiego do ks. Jetowickiego z 5 stycznia 1844 r. 
ducha, z szczególnymi widokami swymi dla nas na przyszłość, czy też nie było tego wszystkiego i byliśmy tylko tymczasowym zgromadzeniem ludzi bez tego wszystkiego. Ja mam mocną w Bogu nadzieję, że pierwsze, niewypawiedzianą ufność w Bogu, że tak" 70. Na drugi zarzut odpowiada, że zakon to dzieło Boże, a nie swiętego. To wewnętrzne przekonanie, że to małe stowarzyszenie jest dziełem Bożym, pozwoliło Jańskiemu przetrwać wszystkie trudnosci i teraz pozwoliło jego duchowym synom zachowac autonomię.

W tym samym czasie podobną propozycje otrzymano od jezuitow ${ }^{80}$. Ks. Semenenko stąd konkluduje: „Pan Bóg nie mógł obu propozycji razem przysłać, a zatem najprostszy wniosek, że żadnej nie przysłal, i że tylko nasze położenie jest takie, że je wywołuje. Bo by przynajmniej nie pozwolił na obie razem, zupelnie $w$ tym samym czasie ${ }^{81 . " ~ S p e c y f i c z n a ~ s y t u a c j a ~} w$ jakiej się znaleźli, utwierdziła ich $w$ przekonaniu, że Bóg powołał ich do specjalnego zadania.

Kiedy Pius IX wstapił na Stolicę Piotrowa, zwrócił swoją uwage na grupę młodych, gorliwych kapłanów - Polakow w Rzymie. Bardzo serdecznie przyjmowal ks. Kajsiewicza, który w memoriale pisemnym i relacjach ustnych wskazywał, jak można przyjść z pomocą ucisnionemu Kościolowi w zaborze rosyjskim ${ }^{82}$. Niebawem zmartwychwstańcy stali się jakby tajną ambasadą polską przy Watykanie ${ }^{83}$, gdyż nie tylko przedstawiali papieżowi swych rođaków, którzy nie chcieli się starać o audiencje przez ambasade rosyjską, lecz także wręczali tajne dokumenty i składali sprawozdania $z$ ważniejszych wydarzeń $w$ Polsce pod zaborami. Budzili w sercach polskich miłośc i wiernosć do Stolicy Apostolskiej. Ambasada rosyjska za demaskowa-

79 Tamże, s. $160-161$.

80 List ks. Semenenki do ks. Kajsiewicza z 8 i 9 lutego 1844 r. Por.: Smolik ow ski, dz. cyt., s. 160-164.

81 Tamże, s. 164.

8219 lipca 1846 r. ks. Ka jsìe wi c z złożył memoriał na ręce papieża Pius a IX w którym postulowal, by Stolica Apostolska wobec rządu rosyjskiego postawiła następujące wymagania:

a) by można było mianować biskupów jeżeli nie doskonałych, to przynajmniej prawowiernych;

b) by bardziej kanonicznie urządzono konsystorze i seminaria;

c) by moźna bylo otworzyć nowicjaty zakonne, szczególnie zakonów żebrzących;

d) domagac się erygowania biskupów dla Syberii, Kaukazu i prowincji południowych.

Nadto ks. Kajsiewicz sugerowal by dla ożywienia wiary i powstrzymania akcji schizmatyckiej beatyfikować Andrzeja Bobolę i kanonizować bł. Józefata $\mathrm{Ku} \mathrm{n} \mathrm{ce} \mathrm{wicz} \mathrm{a;} \mathrm{podnieść} \mathrm{i} \mathrm{rozwinąć} \mathrm{kolegium}$ greckie już $w$ Rzymie istniejące i przetworzyć je w kolegium grecko-słowiańskie; ożywić i przywiązać do Stolicy Apostolskiej duchowieństwo unickie w Galicji i na Wegrzech; postarać się o misjonarzy obrządku słowiańskiego dla wielu milionów Słowian prawosławnych $w$ Turcji. Por.: K a jsie wi c z, dz. cyt., t. III, s. 449.

83 Tamże, s. 450 . 
nie akcji rządowej prześladowała zmartwychwstańców na każdymkroku tak, że nie mogli otworzyć żadnej placówki pod zaborem rosyjskim.

W 1853 r. ks. d'A I z o n, założyciel nowego francuskiego zgromadzenia Wniebowzięcia Matki Bożej (asumpcjonistów), proponował zmartwychwstańcom polączenie się obydwu stowarzyszeń. Ks. d'Alzon chcial się zrzec swego dożywotniego przelożeństwa, przyjąc nazwę Zgromadzenia Zmartwychwstania Pańskiego, oddać zmartwychwstańcom wychowanie duchowe i naukowe i swojej młodzieży, przyjąc Regułę zmartwychwstańców z zastrzeżeniem, że przy nowej redakcji Reguły będą uczestniczyć obywa stowarzyszenia $\mathrm{z}$ równą ilością głosów i wspólnie dokonają wyboru przełożonego polącznych stowarzyszeń.

Warunki, które przedstawił ks. d’Alz on na pewno korzystnie wpłynęlyby na dalszy rozwój stowarzyszenia zmartwychwstańców. Ks. Ka jsiewicz dokładał wszelkich starań, aby do tego polączenia doszło. Ks. Józef $\mathrm{Hube}$, ówczesny przełożony glówny, kategorycznie przeciwstawiał się powyższym propozycjom ${ }^{84}$. Do polączenia obydwu zgromadzień zakonnych nigdy nie doszło.

Jedną $\mathrm{z}$ trosk pierwszych zmartwychwstańców był fakt, że stowarzyszenie po kilkunastu latach istnienia liczylo zaledwie szesciu kaplanow i kilku braci ${ }^{85}$. Czemu przypisać tak nikły rozwój, a raczej stagnację stowarzyszenia?

O. Joachim Bar rozpatrując ten problem, widzi źródło niepowodzeń „w braku jakiegos osrodka centralnego, wok6ł którego mogliby się członkowie skupić, a więc w braku autorytetu wewnętrznego. Zwykle taki autorytet daje $w$ zakonach założyciel. U zmartwychwstańców zmarı główny założyciel (Jański) zanim zgromadzenie przybrało kształt prawny, a inni pierwsi członkowie, każdy wybitny na swój sposób i zasłużony dla zgromadzenia, nie mieli tyle powagi moralnej, aby koło swej osoby skupić wszystkich i rostrzygnąc trudnosci praktyczne, jakie nasuwało życie ${ }^{86}$."

Wydaje się, że tego rodzaju interpretacja nie rozwiązuje calkowicie problemu, gdyż wiele zakonów rozwinęło się dopiero po smierci założycieli, a nawet mimo opuszczenia przez nich zakonu, jak to miało miejsce u ojcow kapucynów. Zródła niepowodzeń należy doszukiwać się gdzie indziej.

Ks. Kajsiewicz analizując stagnacje stanu liczebnego stowarzyszenia, widzi przyczynę $w$ jego skladzie osobowym. W tym bowiem czasie do zmartwychwstańców wstępowali tylko Polacy obarczeni wadami narodowymi ${ }^{87}$. Pewnego rodzaju rozwiązanie widzi ks. Kajsi e-

8í $\mathrm{K}$ wiatk ow ski, dz. cyt., s. $210-211$.

$85 \mathrm{~K}$ a j s i e w i c z, Pisma, t. III, s. 473.

${ }^{86}$ J. Bar, Polskie zakony, Prawo Kanoniczne 4 (1961) 565-566.

${ }^{87} \mathrm{~K}$ wi a tk ow ski, dz. cyt., s. 214. 
wicz $\mathrm{w}$ unii $\mathrm{z}$ asumpcjonistami ${ }^{88}$. Kiedy próba nie udała się, gdyż sprzeciwił się temu ks. Hube, dostrzega rozstrzygnięcie problemu w przyjmowaniu do stowarzyszenia członków innych narodowości i pracy dla nich ${ }^{89}$. Dzięki temu stowarzyszeniu mialoby uniwersalistyczny charakter, tak jak caly Kościoł.

Zdecydowano się na ten krok. Odtąd widzimy faktyczny jego rozwój W 1857 r. stowarzyszenie zaczęło pracować na drugiej półkuli, objęło bowiem misje w Kanadzie.

Dnia 14 września 1860 r. zmartwychwstańcy, dzięki poparciu biskupów, w których diecezjach pracowali, otrzymali dekret pochwalny Stolicy Apostolskiej.

Kiedy Bułgarzy wyrazili gotowość przystąpienia do Unii, z polecenia papieża zgromadzenie w 1863 r. zakłada misję w Adrianopolu, na czele której stanąl niezmordowany apostol, ks. Karol $\mathrm{Ka} \mathrm{c} \mathrm{z} \mathrm{a} \mathrm{n} \mathrm{o} \mathrm{w} \mathrm{s} \mathrm{k} \mathrm{i}{ }^{90}$.

Dnia 25 marca 1866 r., dzięki ofiarom zebranym przez ks. Ka jsiewicza wśród emigracji polskiej, głównie w Kanadzie i w Stanach Zjednoczonych Ameryki Północnej, mogło być zrealizowane pragnienie Jańskiego, a mianowicie utworzenie Kolegium Polskiego w Rzymie ${ }^{91}$.

Widzimy więc, że plan Bractwa Służby Narodowej został powoli realizowany.

88 Tamże, s. 211.

89 Ks. Kajsiewicz pisze w Pamiętniku: „Nie zwiększało się Zgromadzenie $i$ co gorsza nie było nadziei zwiększania, bo emigracja $z$ roku 1830 starzała się, a młodym duchownym z kraju nie pilno było puszczać się na wygnanie. Wobec tak smutnego stanu rzeczy, jednemu ze starszych braci przyszło na myśl, iż ta nieplodnosć pochodzi stąd, iż jesteśmy wylącznie Polakami, rekrutujemy się z wygnańców i pracujemy dla emigracji z natury swojej przechodniej, i niemającej przyszłości: a na grunt polski mimo kilkakrotnych zachodów dostać się nie było podobna. Wnosil zatem, iż należalo przyjmować cudzoziemców i pracować również dla cudzoziemców. Nigdysmy ich w zasadzie nie wykluczali; owszem, mieszkal z nami lat kilka mlody i zdolny kapłan rzymski ksiądz Marchetti: ale poczuł $w$ sobie powolanie do misji afrykańskich i zapracowawszy się rychło, świątobliwie na Malcie życia dokonał. Raczej cudzoziemcom nie przychodziło na myśl zgłaszać się do nas, bo obcy brali nas za zakład wylącznie polski, nazywając nas w Paryżu „prêtres polonais, mission polonaise" a w Rzymie "collegio polacco, preti polachi, congregazione polacca". Nadszedl czas, w którym i pod tym względem rzecz się wyjaśniła $i$ uzupełniła bez żadnego $z$ naszej strony starania i bez żadnej też zasługi. W roku 1853 zjawił się mlody Westfalczyk ... Eugeniusz Fruncken, gorąco prosząc o przyjęcie. Gdy zapytany czy wychowany na chlebie polskim, zechce się po polsku nauczyć, i w razie potrzeby w Polsce pracować, chętnie się na to zgodził i zostal przyjęty." Por.: Kajsiewicz, dz. cyt., t. III, s. 473-474.

${ }_{80} \mathrm{P}$. Smolikow sk i, Założenie misji Księży Zmartwychwstańców $w$ Adrianopolu, Krakow 1897.

$91 \mathrm{~S}$ m oli k ow s ki, Historia Kolegium Polskiego. 
W 1866 r. na zaproszenie biskupa z Texas, otwierają zmartwychwstańcy misję w Stanach Zjednoczonych Ameryki Północnej ${ }^{\mathbf{2 2}}$.

Według sprawozdania ks. Kajsiewicza, w 1871 r. zgromadzenie posiadało następujące placówki:

$1^{\circ}$ we Włoszech:

a) kośció $i$ dom sww. Klaudiusza w Rzymie, służący zarazem za siedzibę Przełożonego Glównego oraz za głowny nowicjat i alumnat;

b) Kolegium Polskie w Rzymie;

c) w diecezji Tivoli - kościół Najświętszej Marii Panny na Metrorelli;

d) nowicjat i alumnat na wyspie Malcie;

$2^{\circ}$ we Francji: misja przy kosciele l'Assumption w Paryż;

$3^{\circ} \mathrm{w}$ Bulgarii: dom misyjny i kolegium w Adrianopolu;

$4^{\circ} \mathrm{w}$ Kanadzie: dom uformowany a przy nim pięć parafii, dziesięć kościołów i szkola;

$5^{\circ}$ w Stanach Zjednoczonych Ameryki Połnocnej:

a) dwie parafie $w$ Texasie;

b) jedna parafia w Michigan;

c) kolegium $w$ diecezji w Lousville;

$6^{\circ}$ w Galicji: kapelania w Jazlowcu.

Zgromadzenie w tym czasie liczyło 78 członków, w tym: 35 kapłanów, 17 kleryków i nowicjuszy oraz 26 braci ${ }^{93}$.

Pierwsza samodzielna placówka na ziemiach polskich powstała w 1880 r. we Lwowie. Papież Le on XIII polecił zmartwychwstańcom założenie internatu dla Rusinów. Założycielem i pierwszym wychowawca był ks. Walerian $\mathrm{Kal}$ in k a ${ }^{94}$. Od $1884 \mathrm{r}$. zaczęto przyjmowac do niego także Polaków.

W tym samym 1884 roku przypada fundacja domu krakowskiego. Założono tam nowicjat, najpierw przy ulicy Szlak 40, a od 1886 r. - przy ul. Eobzowskiej $10^{\text {ต5. }}$.

Rozwój zgromadzenia przedstawia poniższa tabela:

\begin{tabular}{cccccc} 
Rok & Kapłanów & Kleryków & Braci & Nowicjuszy & Razem \\
\hline 1887 & $?$ & $?$ & $?$ & $?$ & 122 \\
1920 & 112 & 15 & 80 & - & 207 \\
1926 & 113 & 47 & 77 & 26 & 263 \\
1932 & 132 & 82 & 60 & 20 & 294 \\
1938 & 176 & 135 & 78 & 29 & 418 \\
1948 & 294 & 40 & 43 & 48 & 425 \\
1967 & 379 & 142 & 56 & 46 & 623 \\
1974 & 343 & 76 & 46 & 19 & 474
\end{tabular}

$92 \mathrm{~K}$ a j s i e w i c z, dz. cyt., t. III, s. 5114 .

${ }^{83} \mathrm{~K}$ a j s i e wic z, dz. cyt., t. III, s. 524-525.

$94 \mathrm{~K}$ wi a t k ow ski, dz. cyt., s. $317-319$.

95 Tamże, s. $320-321$. 
Po drugiej wojnie swiatowej obserwujemy intensywny rozwój zgromadzenia. Pracuje obecnie we Włoszech, Bułgarii, Austrii, Szwajcarii, w Stanach Zjedocznych Ameryki Pólnocnej, Kanadzie i Polsce. Prowadzi misje na Bermudach, w Boliwii, Brazylii i Jerozolimie. Zgromadzenie ma pod swoją opieką: 60 parafii $(19 \mathrm{w}$ prowincji chicagowsklej, $21 \mathrm{w}$ kanadyjskiej, $19 \mathrm{w}$ polskiej i jedną $\mathrm{w}$ Szwajcarii), obsługuje 52 kościoly filialne, 6 kosciolow rektoralnych, 15 kaplic, 8 kapelanii, prowadzi uniwersytet (w Kanadzie), 3 kolegia, 6 szkół zawodowych, niższe seminarium duchowne (w Polsce), posiada jedno wydawnictwo (Stany Zjednoczone Ameryki Północnej), 8 czasopism (jedno we Wloszech, $4 \mathrm{w}$ Stanach Zjednoczonych Ameryki Połnocnej i $3 \mathrm{w} \mathrm{Ka-}$ nadzie) ${ }^{26}$.

$\mathrm{Z}$ powyższego zestawienia widzimy, że zgromadzenie jest zaangażowane $w$ pracy duszpasterskiej, wychowawczej, wydawniczej i naukowej. Większość jednak członków zgromadzenia (198) jest zaangażowana w pracy duszpasterskiej.

\section{Entstehung and Entwicklung der Auferstehungs Kongregation des Herrn}

In der Großen Emigration von Polen befand sich eine nicht große Gruppe von Personen, die den gemeinsamen Gedanken pflegten, ihre Landsleute durch geistige Viedergeburt zu retten. An der Spitze dieser Gruppe stand Adam Mickiewicz. Dort kam man auch den Gedanken, eine polnische Kongregation zu stiften. Diesen realisierte Bogdan Jański (1807-1840) nach langen Suchen und Irren führte sein Weg zu Gott. Nun wurde er ein eifriger Apostel. Er nahm all die Schwere und Bemühungen auf, um seinen Landsleuten, den verlorenen Glauben wiederzugeben. Er war sich dessen bewußt, daß eine. Rechristianisiemung der polnischen Geselschaft keine leichte Aufgabe sei. Sein Wille war, sich auf diejenigen zu stützen, die denselben Ideen anheimgefallen waren: das Bestreben zur persönlichen Vollkommenheit der Landsleute. Bogdan Jański nahm mit seinen Schülern Piotr Semenenko und Hieronim Kajsiewicz am 17. Februar 1836 Wohnung in einen gemieteten Häuschen in der Nâtré Dame des Champs-Straße $\mathrm{Nr} 11$ in Paris. Derartige „Häuschen" wünschte er in allen Ländern Europas zu gründen. Der "Tod überrasche ihn am 2. Juli 1840 und somit schienen seine Pläne gestrichen $\mathrm{zu}$ werden. Sein Werk jedoch wurde von Semenenko und Kajsiewicz aufgenommen. Am 26. März 1842 wurde die erste Klosterregel festgelegt und der Name "Auferstehungsbrüder" angenommen. Die Auferstehungsbrüder informierten den Apostolischen Stuhl über die Situation der Kirche in Polen, sie wurden eine unoffizielle Polnische Botschaft beim Vatican, sie führten Lehrinstitute für die polnische Jugend in der Emigration, sie waren Herausgeber von religiösen Werken, sie veranlassten Andachten in polnischer Sprache für die Emigranten. Im Jahre 1857 präzisierten sie ihr Ziel: 1) Jugendbildung und- erziehung, und dies nicht nur des geistlichen Standes, sondern auch des laizistischen, im christlichen Geiste; 2) Einführung eines

96 Catalogus Congregationis a Resurrectione D.N.J.Ch. 1974, s. 88-89. 
wirklich christlichen Lebens unter den Menschen, und zwar durch Anufnahme von Gemeindarbeiten, Missionsarbeiten, Herausgabe von Zeitschriften und andere apostolische Aufwartung; 3) Verbreitung besonderer zu Ehren Unserer Lieber Frau Muttergottes. Die Kongregation arbeitet zur Zeit in Polen, in Italien, in Osterreich, in den Vereinigten Staaten und Kanada. Missionsarbeiten werden von den Auferstehungsbrüdern auf den Bermuden, in Bolivien und in Jerusalem geführt. 